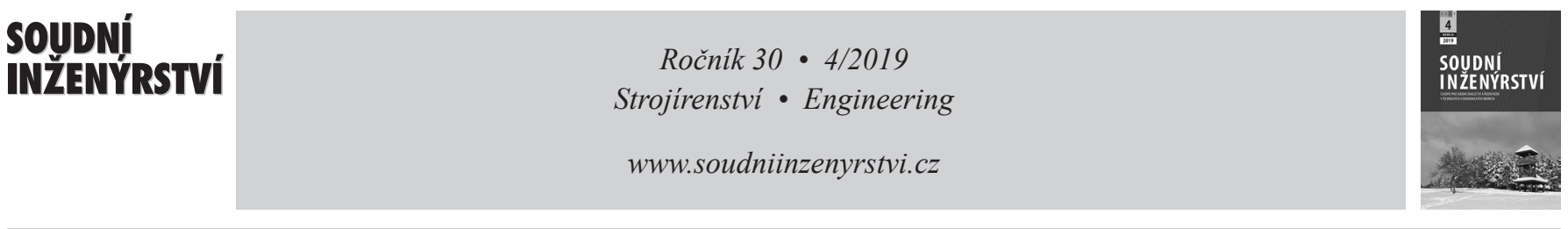

\title{
Možnosti využití válcového dynamometru pro hodnocení stavu vozidel
}

\section{Possibilities of Chassis Dynamometer Using for Vehicle Condition Evaluation}

Adam Polcar ${ }^{*}$, Jiří Čupera

Mendelova univerzita v Brně, Agronomická fakulta

\begin{abstract}
Abstrakt
Článek popisuje možnosti využití vozidlového válcového dynamometru k posuzování technického stavu vybraných funkčních skupin vozidla. Jsou zde popsány princip a možnosti měření pomocí dynamometru, konstrukční uspořádání válcové zkušebny a jednotlivé zkoušky, které je možné na tomto typu zkušeben provádět. $\mathrm{V}$ druhé části článku je popsán postup měření s uvedením př́kladů grafických výsledků praktického měření výstupních parametrů motoru a brzdové soustavy osobního automobilu provedeného v laboratořích Ústavu techniky a automobilové dopravy Mendelovy univerzity v Brně. Článek byl prezentován na konferenci Expert Forensic Science Brno 2019 - ExFoS 2019.
\end{abstract}

Klíčová slova: dynamometr, výkonové parametry motoru, zkoušky brzdového ústrojí, spotřeba paliva, měření emisí.

\section{1. ÚVOD}

Ve znalecké činnosti je možné se setkat s př́ípady, kdy bude nutné posoudit technický stav motoru, příp. vozidla z hlediska jeho výstupních parametrů - výkonu, spotřeby paliva, emisí, brzdných vlastností apod. Z tohoto pohledu je možné provést měření $\mathrm{v}$ provozních, resp. $\mathrm{v}$ terénních podmínkách nebo $\mathrm{v}$ laboratoři. Obě zmíněné možnosti měření mají svoje specifické vlastnosti, výhody a nevýhody. Výhody terénního měření spočivají v rychlém, ekonomicky výhodnějším způsobu posouzení, avšak ve většině případech (bez potrebných snímačů) se jedná pouze o posouzení subjektivní. Dalším úskalím měřeních prováděných v provozu je možnost ovlivnění zkoušek dopravní situací nebo atmosférickými podmínkami. Pro zajištění stálosti okolních podmínek, resp. opakovatelnosti měření je tak výhodné provádět měření v laboratoři. Laboratorní zařízení, které umožnuje simulovat jízdní podmínky-

\section{Abstract}

The article describes the possibilities of using the vehicle chassis dynamometer to assess the technical condition of selected vehicle functional groups. Dynamometer principles and possibilities of measurement, the design of chassis dynamometer and the individual tests that can be carried out on this type of testing are described. In the second part of the article, the measurement procedure are described with presentation of graphical results of practical measurement of engine output and brake system parameters of a passenger car carried out in the laboratories of the Department of Technology and Automobile Transport of Mendel University in Brno are described. The article was presented at the Expert Forensic Science Brno 2019 - ExFoS 2019 conference.

Keywords: dynamometer, engine output parameters, brake system tests , measurement of fuel consumption, emission test

vytvářet odpor proti otáčejícím se kolům nebo hřídeli motoru, se nazývá dynamometr. V praxi je také často používán termín brzda, která významově vystihuje proces, který se při měření uskutečňuje. Tedy zařízení vytváří stejnou výši momentu, jakou generuje spalovací motor, pouze má opačný smysl působení. V systému zkoušení vozidel se využívají dva základní typy dynamometrů - ty které pouze brzdí (nejrozšířenějším typem jsou elektricky-víriivé), a ty které mohou i pohánět (elektrické - synchronní, asynchronní nebo stejnosměrné) [1]. Dynamometry se mohou připojit k motoru přímo prostřednictvím hřídele - na motorových, nebo speciálních traktorových zkušebnách (viz obr. 1), nebo jsou přes řemenový, či řetězový převod propojeny s válci (válcové zkušebny), na které najíždějí kola vozidla.

Motorové zkušebny se nejčastěji vyskytují na specializovaných pracovištích pracující v oblasti vývoje a výzkumu. Měření parametrů motoru na těchto zkušebnách je již vzhledem k nárokům norem 


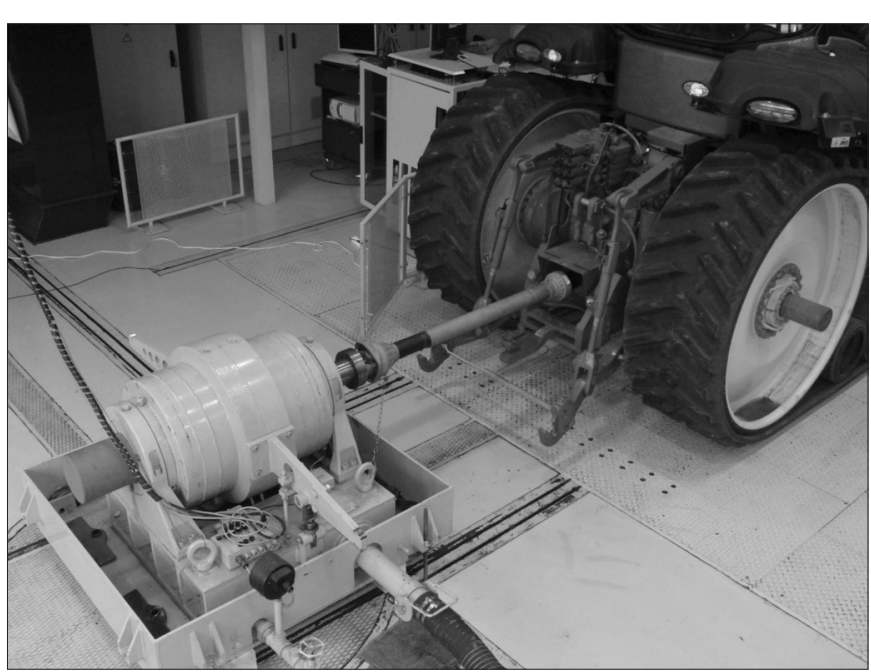

Obr. 1 Měreni výstupnich parametrů motoru přes vývodový hř́del traktoru dle metodiky OECD (Ústav techniky a automobilové dopravy, Mendelova univerzita v Brnè).

Fig. 1 Measurement of engine output parameters via PTO shaft according to the OECD standard (Department of Technology and Automobile Transport, Mendel University in Brno).

měření precizní, což může být doloženo opakovatelností měření a nízkou variabilitou výsledků i mezi různými zkušebnami. Možnou nevýhodou posuzování technického stavu motoru na motorových zkušebnách je př́prava motoru. Je nutné demontovat pohonné ústrojí a umístit jej na stanoviště. To s sebou nese nejen nároky na mechanickou práci, ale $\mathrm{v}$ dnešní době také nutnost instalovat komponenty, které by při jejich absenci znemožňovaly spolehlivost měření, nebo i spuštění motoru, z toho plyne ekonomická a časová náročnost.

Z tohoto důvodu se při hodnocení technického stavu vozidel a při posuzování vlivu různých konstrukčních prvků, paliv apod.,

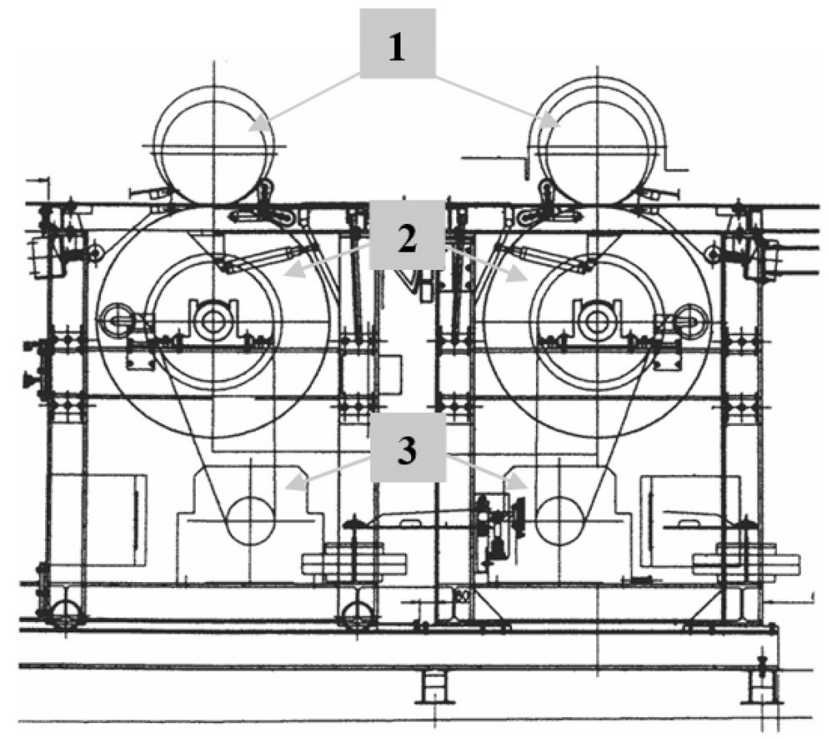

Obr. 2 Schéma automobilové zkušebny 4VDM E120-D; 1 - kola automobilu, 2 -ocelové válce, 3 - elektrické dynamometry SDS 2255604 [2].

Fig. 2 Diagram of vehicle laboratory 4VDM E120-D; 1 - car wheels, 2 -steel rollers, 3 -electrical dynamometer SDS 2255604 [2]. mnohem častěji setkáváme se zkušebnami válcovými (schéma viz obr. 2). Na válcových zkušebnách probíhá zkouška vozidla jako celku (zohlednění vlivu transmise, pneumatik apod.). Při zkouškách je v podstatě nastolen stav odpovídající jízdě na vozovce s jejich přesným definováním. Před měřením vozidla není nutná jeho žádná „Zvláštní“ prŕíprava a vlastní zkouška je časově nenáročná.

Válcové dynamometry jsou univerzální zařízení, která vznikají ze dvou hlavních požadavků, resp. účelů [1]:

- technické - jedná se o zkušební nebo vývojové zkušebny, kde existuje obecný charakter zkoušení (pohonné ústrojí a přenos síly na vozovku) nebo specifický charakter (zkoušení vibrací a hluku, klimatické testy, zkoušení spolehlivosti).

- legislativní - je doménou zkoušení emisních parametrů vozidel pro testy, které jsou obsaženy $\mathrm{v}$ homologacích (např. EHK R83 atp.), dále jsou některé dynamometry konstruovány pro zkoušení elektromagnetické kompatibility EMC či zkoušení bezpečnosti vozidel.

Na válcovém zkušebně spalovací motor přenáší výkon na hnací kola vozidla, ta třením roztáčí zkušební válce dynamometru. K válci je připojen dynamometr, který klade otáčejícímu se kolu brzdný odpor a umožňuje regulaci jeho velikosti. Tento brzdný moment vyvolává reakční moment stejné velikosti ale opačného smyslu. Jelikož válce jsou spojeny s rotorem brzdného zařízení a poháněny koly vozidla, přenáší se reakční moment přes stator na siloměrné zařízení. Měřením velikosti reakčního momentu lze určit obvodové hnací síly na kolech vozidla a při znalosti otáček, resp. rychlosti otáčení je možné vypočítat výkon podle rovnice (1):

$$
P=M_{t} \cdot \omega[\mathrm{W}]
$$

kde:

$$
\begin{array}{ll}
M_{t} & \text { točivý moment }[\mathrm{N} . \mathrm{m}] \\
w & \text { úhlová rychlost }\left[\mathrm{s}^{-1}\right] .
\end{array}
$$

Pro měření točivého momentu se použivá většinou deformačních sil. Moment síly namáhá měřící člen - tenzometr (viz obr. 3) nebo tenzometrickou přírubu, který převádí napětí na deformaci a výsledná hodnota je převedena na sílu resp. moment. Pro určení výkonu je nutno zároveň měřit otáčky klikové hřídele [1].

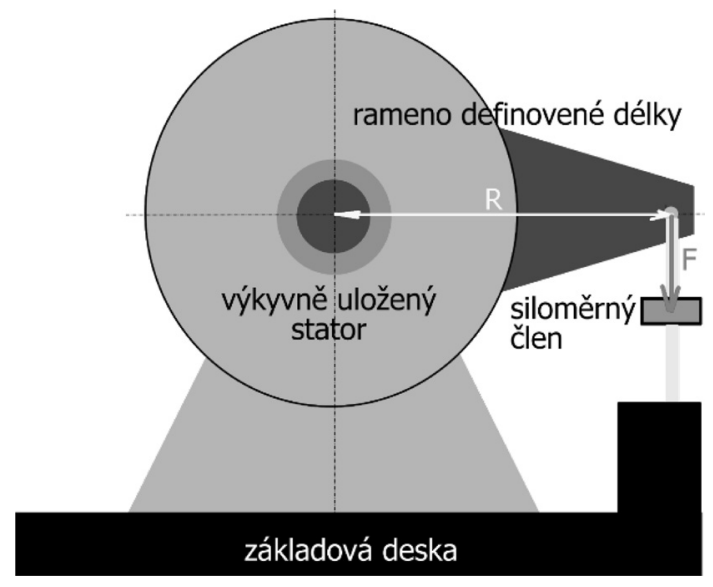

Obr. 3 Princip měřeni dynamometru s tenzometrem [1].

Fig. 3 Principal of dynamometer measurement with strain gauge [1]. 
Mimo měření výkonu a točivého momentu (při $v=$ konst. nebo $F=$ konst., dynamické zkoušky) se válcový dynamometr používá i pro další typ zkoušek, např. pro zkoušky brzdového ústrojí (pomaloběžné, rychloběžné, dynamické), kalibrační zkoušky (napřr. určení pasivních odporů vozidla, kontrolu rychloméru, otáčkoměru, pohonu $4 \times 4$, apod.). Jízdní zkoušky je možné provádět podle vlastního nastavení nebo podle předem předepsané metodiky v čase jako např. u exhalačních testů EHK. Při zkouškách je samozřejmostí např. měření složení výfukových emisí a spotřeby paliva.

Stejně jak požadavky na přesnost snímačůn, tak i podmínky měření motorů jsou specifikovány normami. Pro motory automobilové se v ČR používají normy UN ECE, pro zkoušení např. zemědělských traktorů pak mezinárodní metodika OECD [3]. Normy jsou postupem ke zkoušení jednotlivých typů motorů. Jsou použitelné pro hodnocení jejich výkonnosti, zvláště s ohledem na vypracování křivek pro výkon a specifickou spotřebu paliva při plném zatížení v závislosti na otáčkách motoru.

Díky velkému vlivu na výkonové parametry definují normy též rozmezí atmosférických podmínek měření, resp. vlastnosti spalovacího vzduchu. Formulace stavu vzduchu vychází ze tří základních parametrů: tlaku, teploty a vlhkosti. Obvyklá hodnota pro barometrický tlak je $100 \mathrm{kPa}$, teplotu: $25^{\circ} \mathrm{C}$ a vlhkost: $30 \%$ rel. Vliv tlaku se neodráží pouze ve změně výkonových parametrů motoru, ale je doprovázen negativními jevy, z nichž nejmarkantnější je nárůst ložisek detonačního spalování, které mohou vést i k destrukci motoru.

Aby byl zkušební proces objektivní a opakovatelný, pak je nutné, aby výsledky měření byly srovnatelné i v odlišných podmínkách, což se děje převedením na standardní podmínky pomocí tzv. korekčního součinitele. Tento součinitel je bezrozměrný a naměřený výkon se jím pouze násobí. Normy, které definují vztahy pro výpočet korekčního koeficientu př́slušného motoru a jeho maximální hodnoty, se v České republice nejčastěji používají: ČSN 30 2008, ISO DIN 1585 a EHK R85. Zkušební podmínky, tak musí ležet co nejblíže ležet referenčním podmínkám, aby se korekční faktor udržel blízký standardním podmínkám [1].

\section{METODIKA MĚŘENÍ NA VÁLCOVÉM DYNAMOMETRU}

Jako př́íklad měření vozidla na válcovém dynamometru bude popsáno měření realizováno na válcovém dynamometru Ústavu techniky a automobilové dopravy Mendelovy univerzity v Brně. Jedná se o monoválcovou zkušebnu. Konstrukční řešení této zkušebny (označení: 4VDM E120-D) vychází z tuhých základních rámů, na kterých jsou umístěna ložiska a válce o průměru $1,2 \mathrm{~m}$ (velký průměr vzhledem $\mathrm{k}$ potlačení negativních jevů deformace pneumatiky a přiblížení stavu jízdy po vozovce), stojny a základní rámy s elektrickými dynamometry. Tyto rámy se stojinami tvoří základní bloky jednotlivých os. Blok přední osy je umístěn pevně, blok zadní osy posuvně (nastavovaný podle požadovaného rozvoru vozidla), společně s přední osou válcového dynamometru pro traktory VDU-E270T-E150T, jelikož zkušebna je tvořena nejenom z dynamometru pro osobní automobily, ale i z duoválcové zkušebny pro traktory. Spojení levého a pravého válce zajišt'uje elektricky ovládaná frikční spojka. Propojení válcových jednotek s elektrickými dynamometry typu SDS 2255604 je provedeno
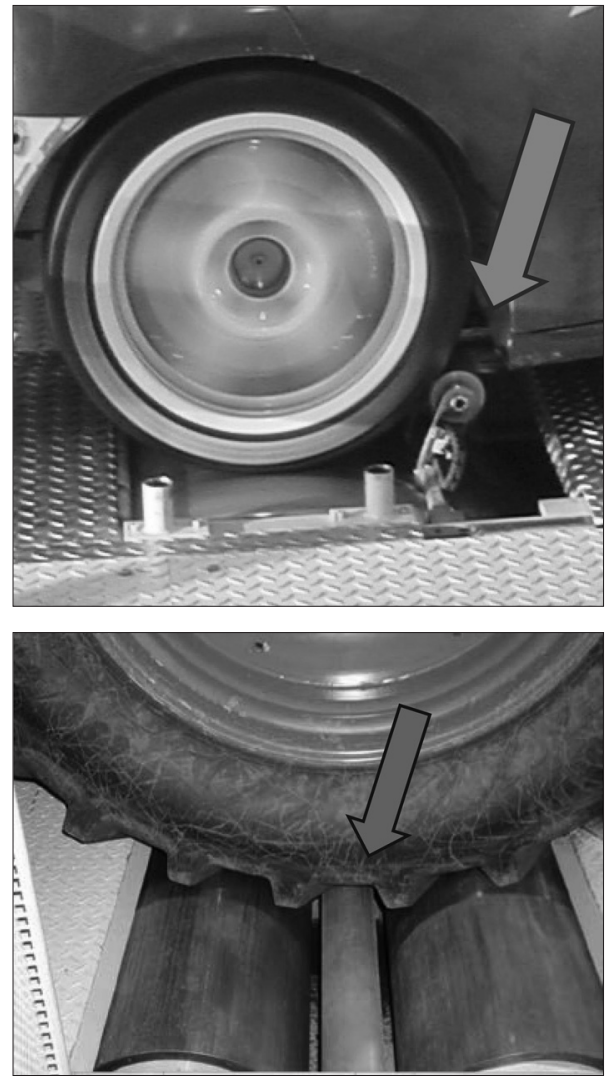

Obr. 4 Skluzová rolna válcového dynamometru pro osobni automobily (vlevo) a pro traktory (vpravo).

Fig. 4 Sliding roller of chassis dynamometer for cars (left) and for tractors (right)

pomocí ozubených řemenů. Každý válec je vybaven pneumaticky ovládanými brzdami pro umožnění najetí vozidla a bezpečnostní zabrzdění. Každý válec obsahuje skluzové rolny (viz obr. 4), které

Tab. 1 Technické parametry válcové zkušebny 4VDM E120-D pro osobni automobily [4].

Tab. 1 Technical parameters of chassis dynamometer 4VDM E120-D for cars [4].

\begin{tabular}{lc}
\hline Parametr & Specifikace \\
\hline Max. zkušební rychlost $[\mathrm{km} / \mathrm{h}]$ & 200 \\
Max. výkon na nápravu $[\mathrm{kW}]$ & 240 \\
Max. hmotnost na nápravu $[\mathrm{kg}]$ & 2000 \\
Průměr válce [m] & 1,2 \\
Šíŕka válce [mm] & 600 \\
Povrch válce & zdrsnění RAA 1,6 \\
Hmotnost válců (každá náprava) $[\mathrm{kg}]$ & 1130 \\
Min. rozvor [mm] & 2000 \\
Max. rozvor [mm] & 3500 \\
Rozsah měření rychlosti $[\mathrm{km} / \mathrm{h}]$ & $0-200$ \\
Rozsah měření sil [kN] & $4 \mathrm{krát} 0-5$ \\
Přesnost měření rychlosti $[\mathrm{km} / \mathrm{h}]$ & $\pm 0,05$ \\
Přesnost měření sil [\%] & $\pm 1,5$ \\
Přesnost regulace rychlosti [\%] & $\pm 1,5$ \\
\hline
\end{tabular}


měří skutečné otáčky kola vozidla a následně se vyhodnocuje skluz při brzdění a akceleraci [4].

Dynamometry jsou napájeny z digitálních měničů. Statory dynamometrů jsou výkyvně uloženy v ložiscích. Moment působící na stator je snímán pomocí tenzometrického snímače. Použité stejnosměrné dynamometry mohou pracovat jak v generátorovém tak i v motorickém režimu. Při práci v generátorovém režimu je možno vyrobený elektrický proud dodávat do sítě. Chlazení dynamometrů je prostřednictvím vzduchu [4].

Technické parametry vozidlové válcové zkušebny 4VDM E120-D pro osobní automobily jsou uvedeny v tab. 1.

\subsection{Druhy měřených parametrů}

\subsubsection{Měření výkonových parametrů}

Jak již bylo zmíněno v úvodu, přenos výkonu z motoru je realizován přes převody a hnací kola na válce zkušebny. Hnací výkon na kolech je pak dán součinem podle rovnice (2):

$$
P_{e}=P_{h}+P_{z}[\mathrm{~W}],
$$

kde:

$P_{h} \quad$ hnací výkon [W],

$F_{h} \quad$ hnací síla na obvodu kola $[\mathrm{N}]$,

$v \quad$ obvodová rychlost kola $[\mathrm{m} / \mathrm{s}]$.

Pro výpočet výkonu motoru je důležité znát i výkon ztrátový, resp. výkon na překonání pasivních odporů (valivého odporu pneumatik, převodů atd.). Zjištování ztrátového výkonu probíhá pomocí dynamometru, který v motorovém režimu roztáčí přes válce kola vozidla (platí pro statické zkoušky výkonu, pro dynamické zkoušky platí měření pasivních ztrát doběhem) a současně zaznamenává sílu a obvodovou rychlost.

Výpočet výkonu motoru je pak podle rovnice (3):

$$
P_{e}=P_{h}+P_{z}[\mathrm{~W}],
$$

kde:

$$
\begin{array}{ll}
P_{e} & \text { efektivní výkon motoru [W], } \\
P_{h} & \text { hnací výkon na obvodu kola }[\mathrm{W}], \\
P_{z} & \text { ztrátový výkon (pasivní odpory) }[\mathrm{W}] .
\end{array}
$$

Výpočet točivého momentu motoru je z naměřených otáček a vypočteného výkonu motoru podle rovnice (4):

$$
M_{t}=\frac{P_{e}}{\omega}=\frac{P_{e}}{2 \pi n}[\text { N.m }],
$$

kde:

$$
\begin{array}{ll}
P_{e} & \text { efektivní výkon motoru }[\mathrm{W}], \\
\omega & \text { úhlová rychlost motoru }[\mathrm{rad} / \mathrm{s}], \\
n & \text { otáčky motoru }[1 / \mathrm{s}] .
\end{array}
$$

Koncepční řešení zkušebny umožňuje provádět dynamickou zkoušku a statickou zkoušku výkonu. Při dynamické zkoušce je motor krátkodobě zatížen odporem setrvačných hmot během jejich roztáčení. Důležité je proto znát momenty setrvačnosti všech roztáčejících se částí. Pokud nejsou tyto hodnoty přesně známy, mají výsledné hodnoty dynamické zkoušky pouze informativní charakter. Během této zkoušky dále nedochází ke stabilizaci vnitřních teplot motoru (povrchové teploty spalovacího prostoru, proudění v sacím a výfukovém potrubí atd.), což může způsobit posunutí maximálního výkonu do nižších otáček a následnou deformaci výkonové křivky. Dynamická zkouška se z tohoto důvodu využívá pouze pro získání základních parametrů (maximálního výkonu a točivého momentu, maximálních otáček atd.), které jsou důležité pro nastavení statického měření otáčkové charakteristiky [5]. Statická měření se provádí při konstantních otáčkách motoru, který je zatížen dynamometrem. Záznam hodnot probíhá až po stabilizaci teplot a proto se již naměřené hodnoty dají využít pro přesné hodnocení parametrů motoru. Záznam probíhá definovaně dlouhou dobu, následuje zprůměrování dat a uložení do paměti rrídícího počítače zkušebny. Následná korekce naměřených hodnot na atmosférické podmínky probíhá automaticky.

\subsubsection{Měrení spotřeby paliva}

Pro měření spotřeby paliva se v systému zkoušení vozidel nejčastěji využívají hmotnostní průtokoměry. Objemové průtokoměry bývají zatíženy chybou, která souvisí s teplotní roztažností kapalin. Příkladem hmotnostních průtokoměrů používaných při měření jsou průtokoměry Coriolis Sitrans FC MassFlo Mass 6000 (viz obr. 5). Je nutné používat dva diferenciálně zapojené. Jeden průtokoměr je umístěn na př́vodu paliva k motoru a druhý ve vratném potrubí z motoru. Výsledná spotřeba paliva je pak rozdíl naměřených hodnot obou průtokoměrů.

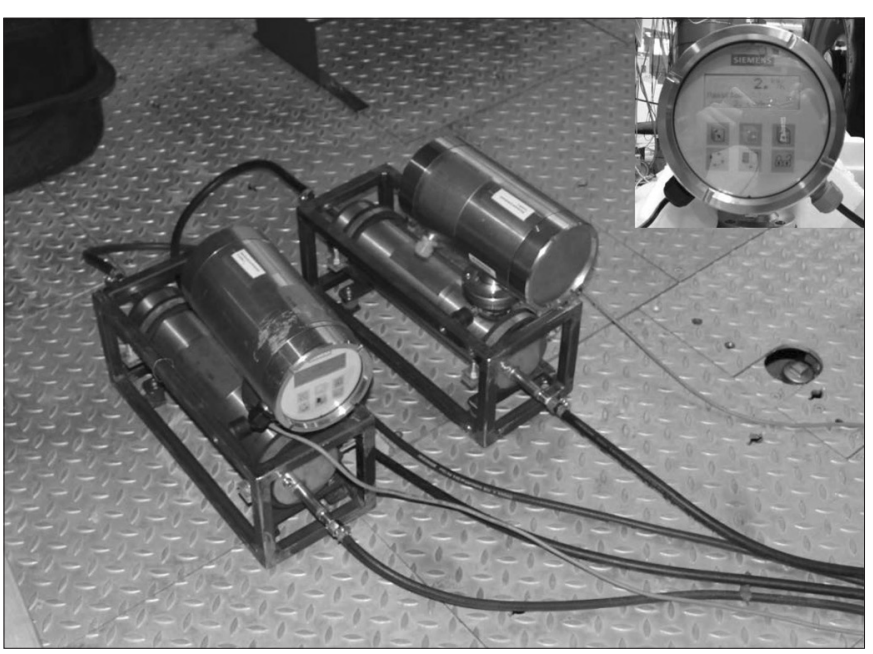

Obr. 5 Hmotnostní průtokomèry

Coriolis Sitrans FC MassFlo Mass 6000

Fig. 5 Mass flowmeters

Coriolis Sitrans FC MassFlo Mass 6000.

\subsubsection{Měření emisí}

Pro měření emisí se v laboratořích používá emisní systémová analýza značky Bosch ESA (viz obr. 6). ESA je modulárně řešený systém. Modul analyzátoru ETT 8.70 provádí měření čtyř základních složek výfukových plynů $\mathrm{CO}, \mathrm{CxHy}, \mathrm{CO}_{2}, \mathrm{O}_{2}$ a z nich pak vypočítává hodnotu součinitele přebytku vzduchu lambda pro právě měřené palivo. Modul ETT 8.71 obsahuje snímače pro měření $\mathrm{NO}_{\mathrm{x}}$. Pomocí přistroje ESA je možné kromě plynných emisí měřit otáčky motoru, součinitel přebytku vzduchu $\lambda$, teplotu oleje, nasávaného vzduchu a výfukových plynů. Př́stroj dále dokáže změřit předstih a dynamický předvstřik pomocí stroboskopické 


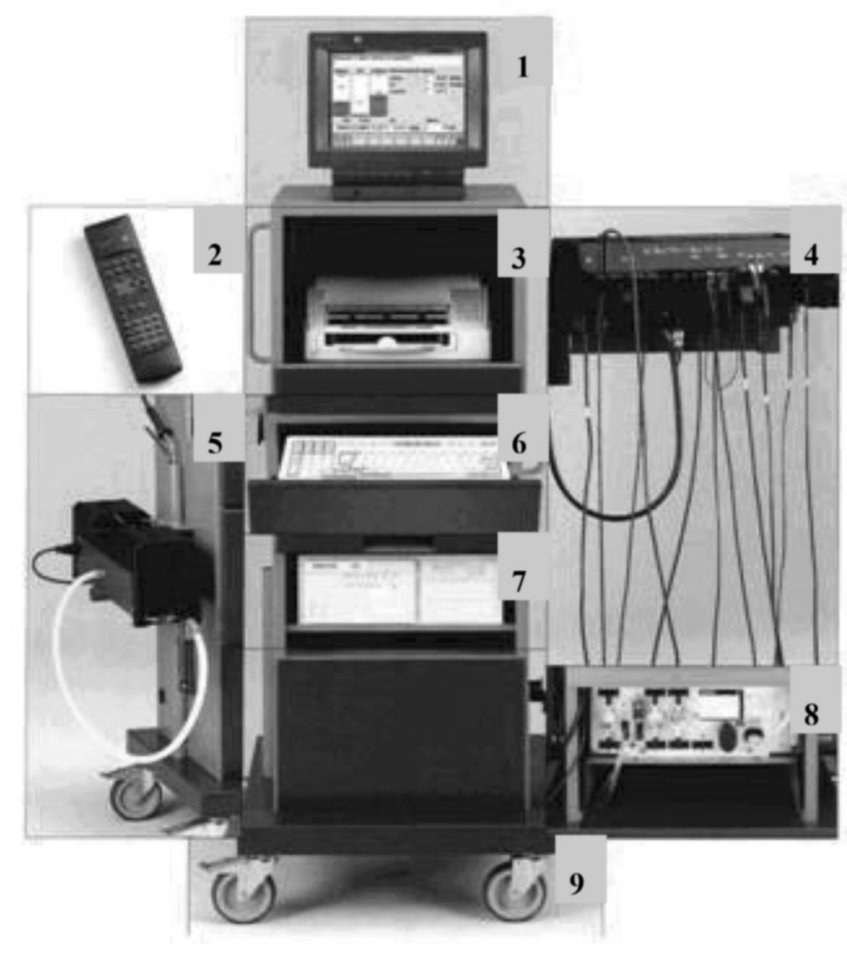

Obr. 6 Sestava systému Bosch ESA; 1 - monitor, 2 -dálkové ovládání, 3 - tiskárna, 4-méř́cí modul MTM Plus, 5-modul opacimetru RTM 430, 6-klávesnice, 7 - PC modul, 8-modul analyzátoru ETT 008.70-1, 9 - dílenský vozík [2].

Fig. 6 Bosch ESA system; 1 - monitor, 2 - remote control,

3 - printer, 4-MTM Plus measuring module, 5-RTM 430 opacimeter module, 6-keyboard, 7 - PC module, 8 - ETT 008.70-1 analyzer module, 9 -workshop trolley [2].

lampy nebo snímače HÚ a nabízí i funkci multimetru. Součástí softwaru ESA je databanka předepsaných hodnot některých vozidel.

\subsubsection{Snímání dalších hodnot}

Pro snímání dalších provozních veličin, které jsou nutné z hlediska hodnocení měření je možno využívat sít' vozidla CAN-Bus. Topologie sítě CAN-Bus umožňuje nejenom vzájemnou komunikaci mezi řídícími jednotkami, ale také vyčítání údajů pro potřeby diagnostiky celého systému. V této souvislosti se naskytuje možnost využívat sít', resp. data $\mathrm{z}$ interních snímačů pro potřeby měření vozidel nejenom v laboratoři, ale i v provozu. Vozidlo se při terénních měření nemusí osazovat externími čidly, které je v mnoha případech velmi obtížné. Osazení vozidla snímači je rovněž drahé a časově náročné. Odečítání relevantních dat ze sběrnice CAN je naproti tomu poměrně jednoduché a také levné. Určitým problémem, který velmi často nastává je správnost těchto dat. Proto je vhodné a v některých př́padech i nutné pro zajištění požadované přesnosti měření provést ocejchování takto získaných dat pomocí přesných laboratorních měřících přístrojů [6].

Pro zpracování, vizualizaci a ukládání signálů z interních snímačů vozidla je možné vytvořit proprietální software např. pomocí programu LabVIEW od společnosti National Instruments.

\subsubsection{Zkoušky brzdového ústrojí}

Dalším typem testů, které lze na válcovém dynamometru provádět jsou testy brzdového ústrojí. Zkoušky se rovněž provádí jak statickou, tak dynamickou metodou. Dynamická zkouška brzd je nejvíce reálným testem, který se blíží k brzdným podmínkám v provozu. Vozidlo je možné brzdit z rychlosti až okolo $200 \mathrm{~km} / \mathrm{h}$. Kinetická energie, která vzniká $\mathrm{v}$ rotačních dílech válcové zkušebny a v rotačních dílech vlastního vozidla, je mařena brzdovou soustavou. Při testu jsou zaznamenány rychlosti a dráha jednotlivých kol a to vše v závislosti na čase. Prvním krokem testu je zadání potřebných hodnot do počítače zkušebny. Následuje roztočení kol vozidla elektromotory na předem stanovenou jmenovitou obvodovou rychlost. Poté řidič sešlápne brzdový pedál (definovanou silou) a dojde ke klesání obvodové rychlost kol. Řidič má sešlápnutý brzdový pedál do té doby, než se kola vozidla úplně zastaví.

Statická metoda na rychloběžné válcové zkušebně je podobným testem zkoušení brzd jako př̀i zkoušení na pomaloběžné zkušebně stanici technické kontroly, s tím rozdílem, že je možno pracovat s rychlostmi až $200 \mathrm{~km} / \mathrm{h}$. Při testu se kola roztočí pomocí elektromotorů válcové zkušebny a při brzdění tyto elektromotory udržují konstantní rychlost, která je stanovena na začátku měření. Na rozdíl od dynamické metody měření se brzdové zařízení zkouší jen při vypnutém systému ABS. Na začátku měření se zadají hodnoty rychlosti, při kterých bude vozidlo brzděno do počítače zkušebny. Následuje roztočení kol vozidla elektromotory na předem dohodnutou rychlost např. $5 \mathrm{~km} / \mathrm{h}, 80 \mathrm{~km} / \mathrm{h}, 130 \mathrm{~km} / \mathrm{h}$. Řidič sešlápne brzdový pedál a elektromotory válcové zkušebny udržují konstantní nastavenou rychlost válců. Brzdový pedál je sešlápnut jen krátkou dobu, současně se kontroluje se, zda brzdové kotouče se nezbarvují do červena nebo pneumatiky nejeví známky př́ípadné deformace. Po definované době řidič odbrzdí a válce zkušebny zastaví kola vozidla.

Snímání hodnot je s frekvencí $18 \mathrm{~Hz}$.

\subsection{Př́íprava měření vozidel na válcové zkušebně}

Po zbavení drobných nečistot (bláta a drobných kamínků) $\mathrm{v}$ běhounu pneumatik následuje kontrola technického stavu a tlaku huštění pneumatik. Po úpravě rozvoru předních a zadních válců podle měřeného vozidla následuje vjetí vozidla na válce. Sjetí vozidla $\mathrm{z}$ válců při zkoušce je zabráněno jeho ukotvením k podlaze zkušebny. Kotvení se provádí pro přední a zadní část vozidla pomocí konstrukcí opatřených pryžovými polštáři (viz obr. 7). Tyto polštáře zachycují dynamické síly vznikající v průběhu zkoušky vozidla. K dodatečné stabilizaci vozidla je možno využít tkaninové popruhy.

Po stabilizaci vozidla následuje situování ventilátorů před vozidlo pro chlazení motoru během zkoušky a připojení odsávacího zařízení ke konci výfukového potrubí pro odvod spalin. Ventilátory jsou ovládány rúídícím softwarem zkušebny a stejně tak i zařízení spalinového hospodářství. Podtlak v místnosti lze regulovat od 5 do $300 \mathrm{~Pa}$, príčemž vyměněné množství vzduchu činí až $25000 \mathrm{~m}$ 3/h. Spalinové ventilátory lze regulovat ručně či v závislosti na odebíraném výkonu motoru a to až do $24000 \mathrm{~m}^{3} / \mathrm{h}$. Posledním krokem je zadání potřebných údajů do počítače regulace, jako je např. hmotnost vozidla, převodové poměry jednotlivých převodových stupňů apod. 

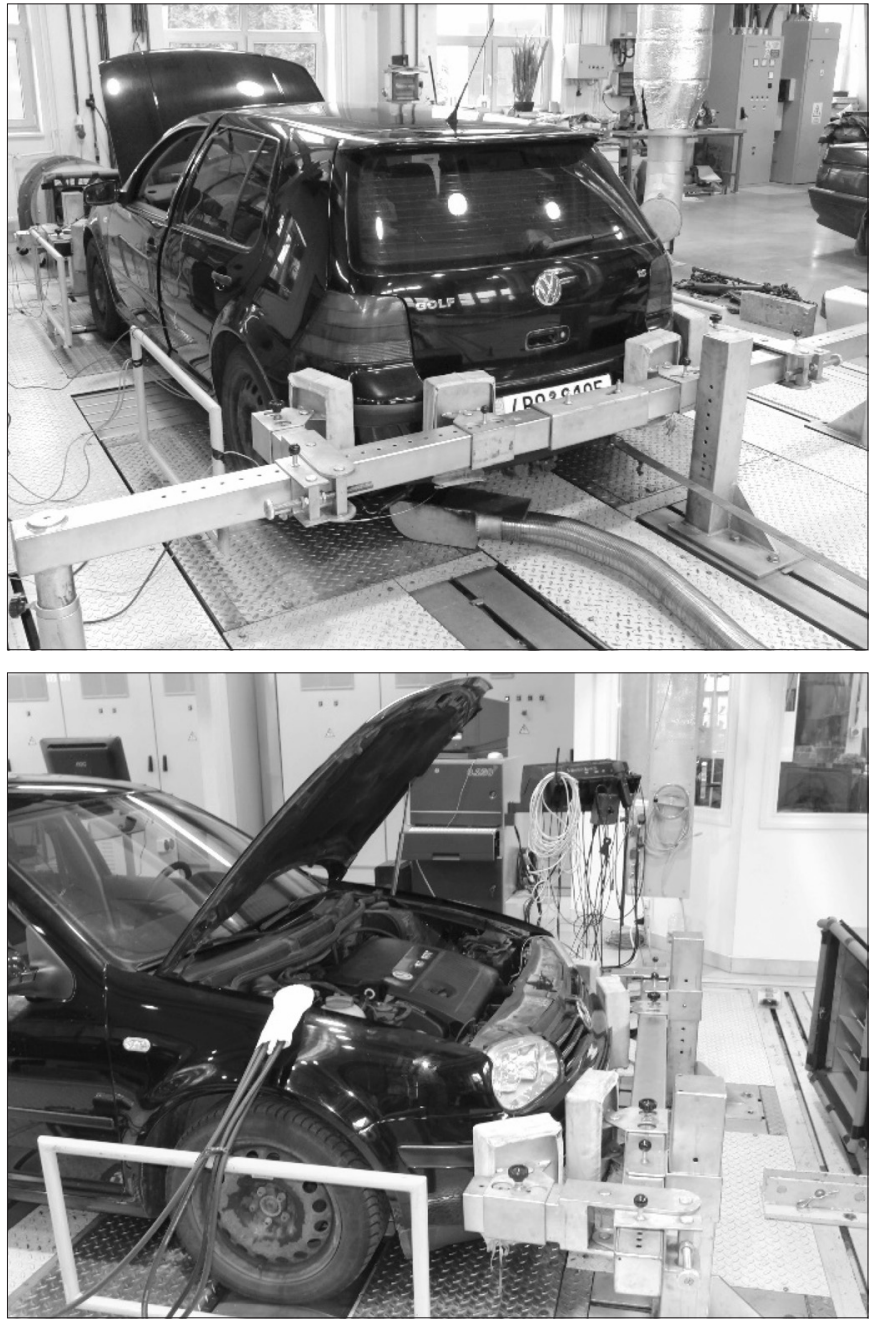

Obr. 7 Pohled na zadní a přední ukotvení automobilu Volkswagen Golf 1.6 [2].

Fig. 7 View of the rear and the front fixation of vehicle Volkswagen Golf 1.6 [2].
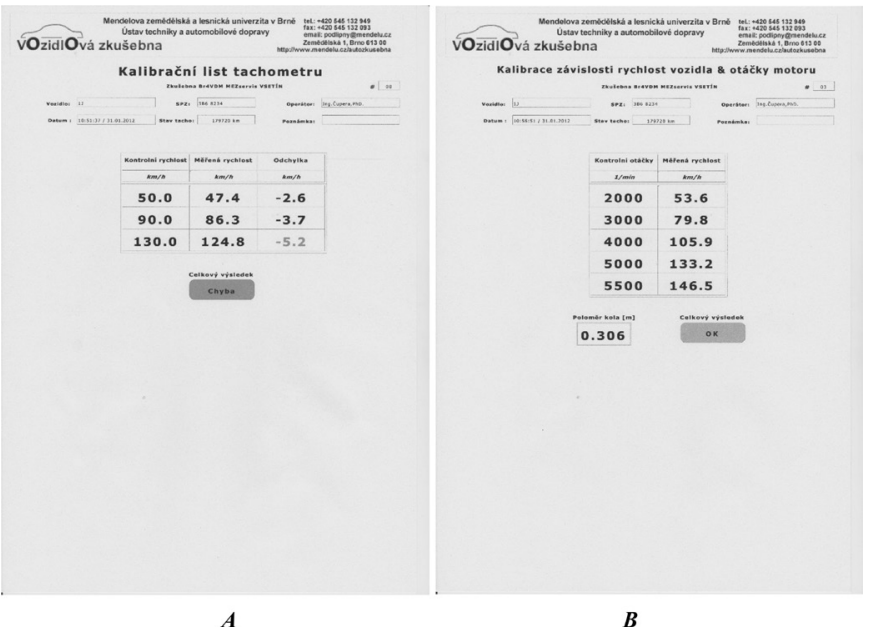

Obr. 8 Protokol z kalibrace tachometru a otáček motoru. Obr. 8 Speedometer and engine speed calibration report.

\subsection{Průběh zkoušek}

Zkouška na válcové zkušebně se musí provádět na příslušný rychlostní stupeň. Zpravidla se rychlostní stupeň volí vyšší. Př́i nízkých rychlostech by při měření velkých výkonů docházelo k prokluzu hnacích kol na zkušebních válcích a tedy $\mathrm{k}$ naměření nekorektních hodnot.

Pro zajištění statistické významnosti jsou zkoušky zpravidla minimálně třikrát opakovány. Po záznamu jednotlivých měřených veličin jsou data kontinuálně odesílána do počítače zkušebny, kde jsou ukládána do souboru ve formátu .xls. Současně je z každé zkoušky vyhotoven protokol z měření.

Zkouška se skládá ze tří kalibračních měření (pro získání příslušných údajů pro zkoušky, např. dynamického poloměru kola, pasivních ztrát) a vlastního měření výkonových parametrů, nebo výstupních parametrů brzd. Mezi kalibrační měření patří:

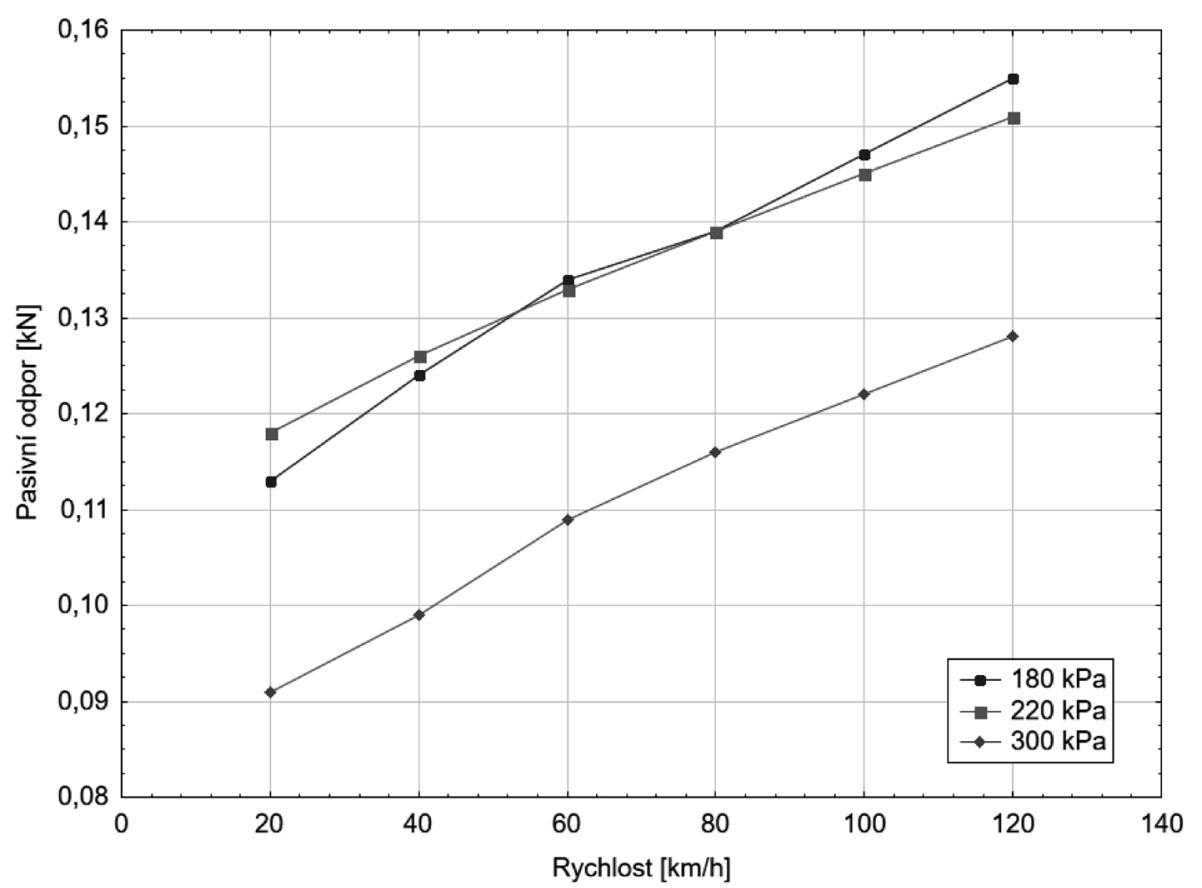

Obr. 9 Závislost pasivniho odporu vozidla při různém tlaku huštěni pneumatik na jeho rychlosti.

Fig. 9 Dependence of vehicle passive resistance on speed at different inflation pressures of tires. 
- kalibrační zkouška tachometru - při které se porovnává rychlost vozidla s rychlostí udávanou na tachometru (protokol z kalibrační zkoušky je uveden na obr.8A),

- kalibrace závislosti rychlosti vozidla na otáčkách motorupři které se zjišt'uje jaké rychlosti (při zařazení př́slušného rychlostního stupně) odpovídají daným otáčkám motoru (protokol je uveden na obr.8B),
- kalibrace pro statické zkoušky výkonu - při kterých se zjišt'ují pasivní odpory vozidla v závislosti na jeho rychlosti. Grafická výstup z měření pasivního odporu vozidla při posuzování vlivu tlaku huštění pneumatik je uveden na obr 9.
Obr. 10 Vnějšš otáčková charakteristika vybraných parametrů. Fig. 10 Engine performance characteristic of selected parameters.

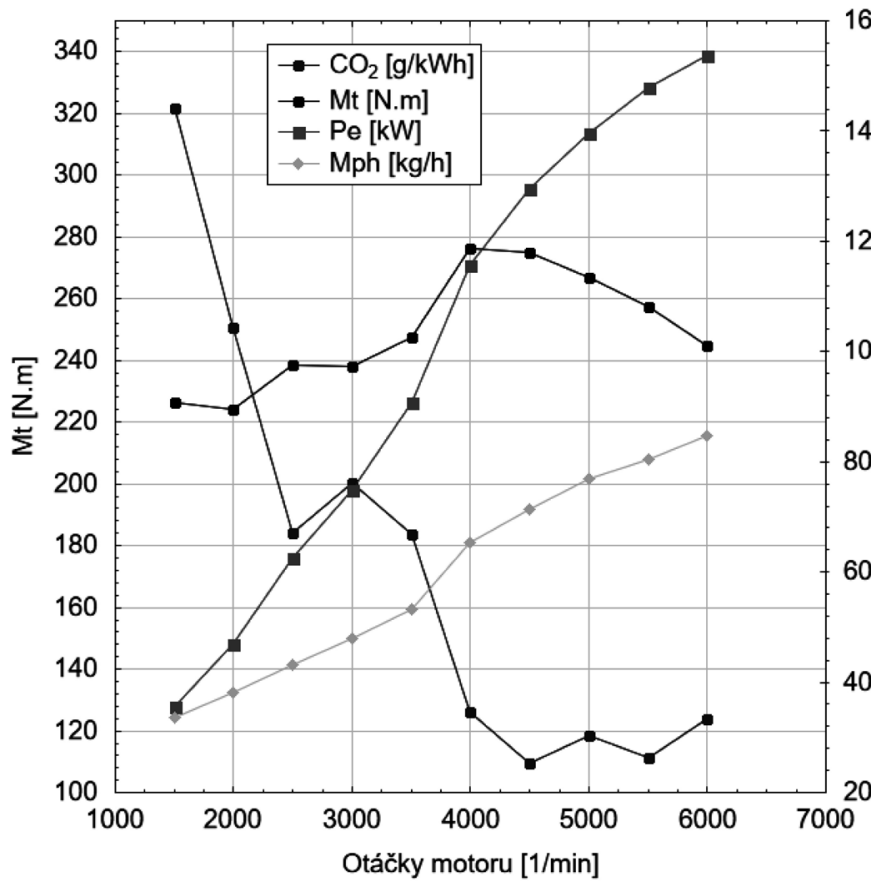

160

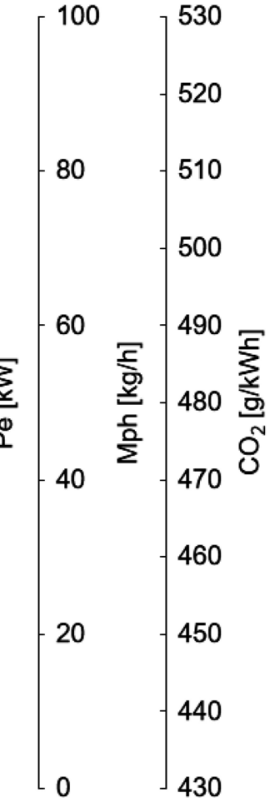

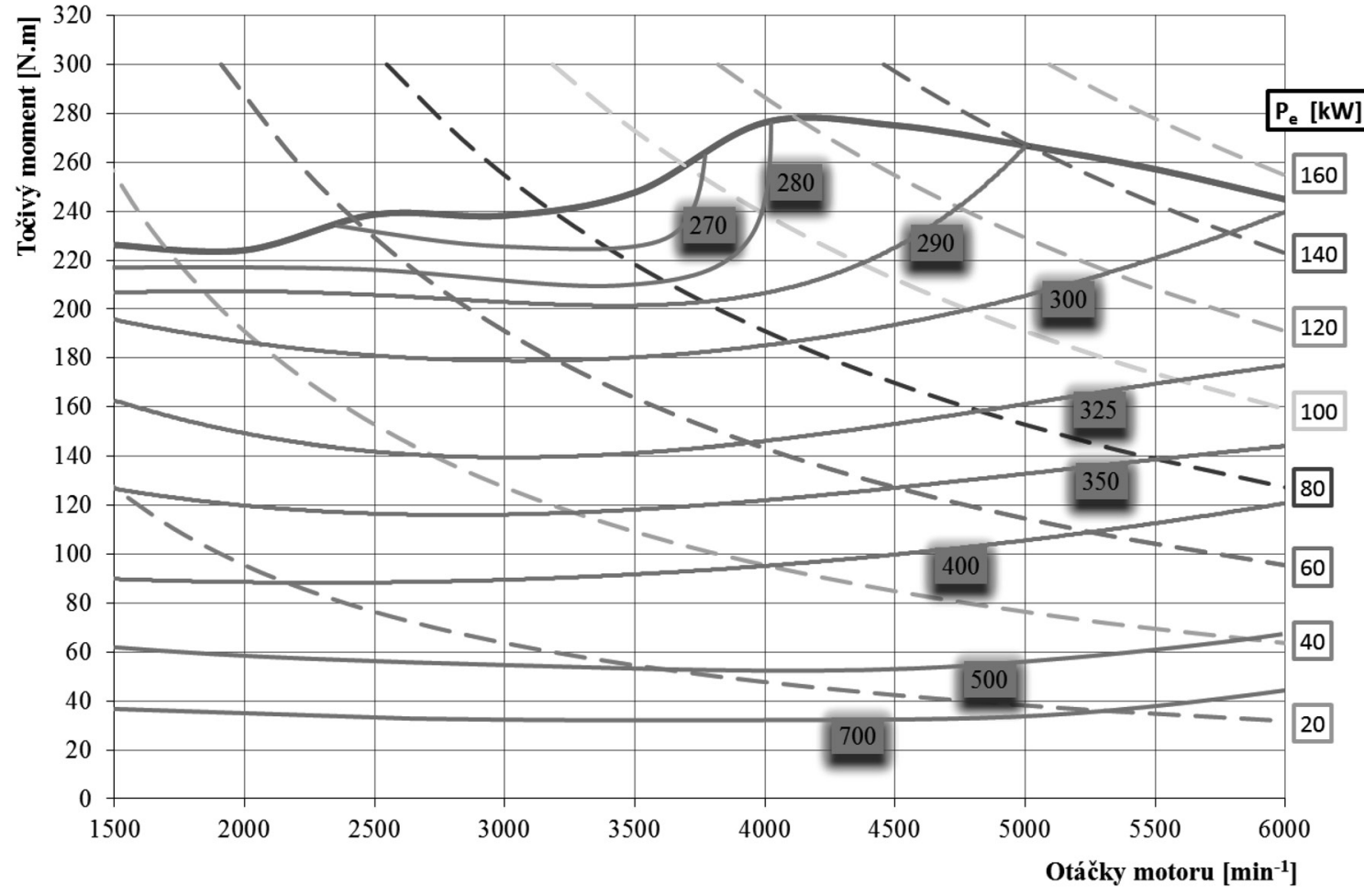

Obr. 11 Úplná charakteristika zážehového motoru s vynesením křivek konstantního výkonu a oblastmi s konstantními mérnými spotřebami.

Fig. 11 Brake specific fuel consumption plot of the spark-ignition engine with the engine output constant curves and constant specific fuel consumption areas. 

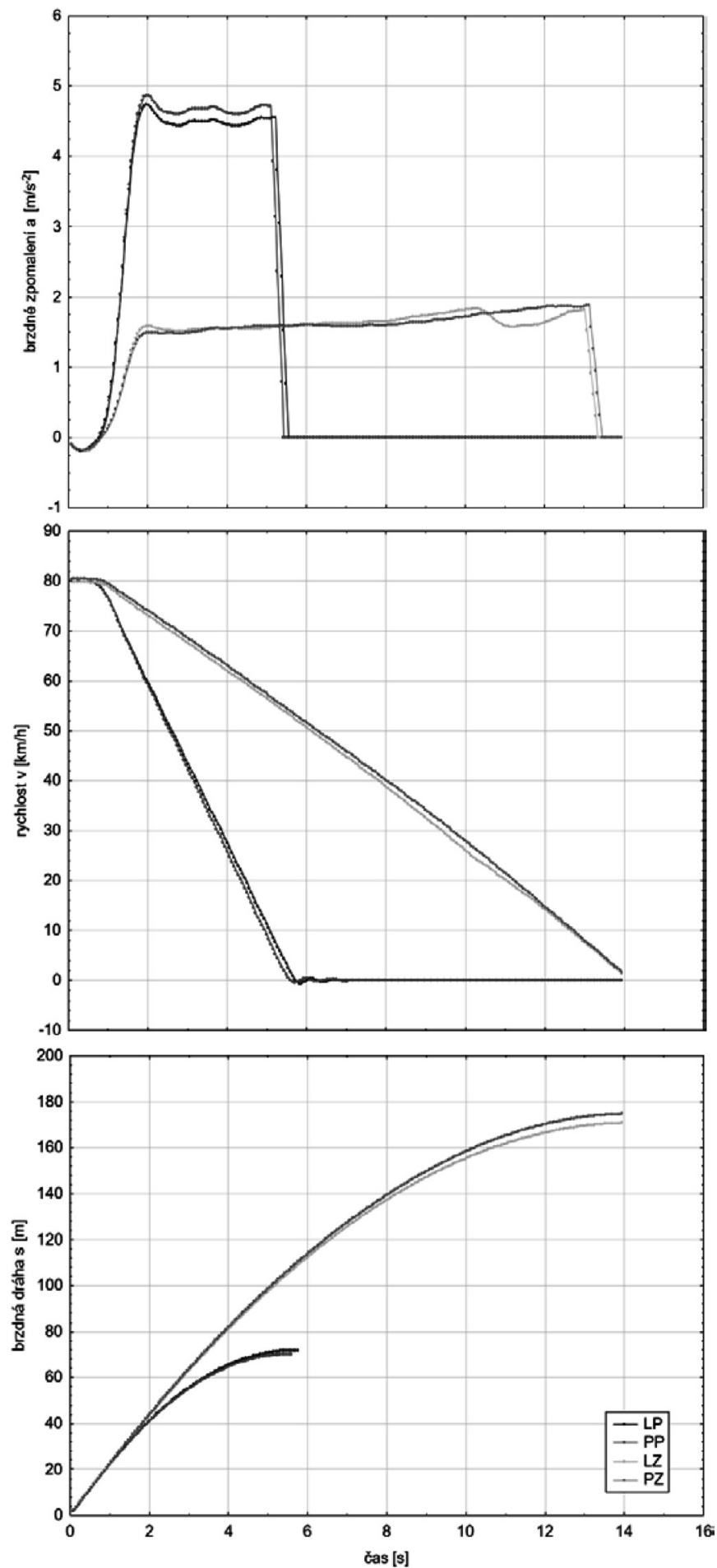

Obr. 12 Průběh brzdného zpomalení, rychlosti a brzdné dráhy $v$ zavilosti na čase (dynamická zkouška, síla na brzdový pedál $50 \mathrm{~N}$, systém ABS deaktivován, vozidlo VW Golf IV 1,6).

Fig. 12 Deceleration, speed and breaking distance depending on time (dynamic test, brake pedal force $50 \mathrm{~N}$, ABS system deactivated, VW Golf IV 1.6 vehicle).

Z grafické závislosti (obr. 9) je možno zjistit vliv tlaku huštění na pasivní odpor vozidla, vyjádřený $\mathrm{v}$ síle $\mathrm{v}$ jednotkách $[\mathrm{kN}]$. Po vynásobení síly rychlostí vozidla je pak možné určit, jak velký výkon motoru vozidla se spotřebuje na ztráty způsobené valením pneumatiky a transmisí od motoru ke kolům. Při rozboru naměřených dat je možné zjistit nejenom celkové pasivní ztráty, ale i pasivní ztráty jednotlivých kol.

K dalším krokům patří již vlastní dynamická a statická zkouška výkonu či brzdového ústrojí. Na obr. 10 je uveden př́íklad výsledků vybraných parametrů z měření vnější otáčkové charakteristiky zážehového motoru osobního automobilu.

Ve vnější otáčkové charakteristice je vynesena závislost výkonu, točivého momentu, spotřeby paliva a měrné produkce emisí oxidu uhličitého $\mathrm{v}$ závislosti na otáčkách motoru. V př́ípadě, že při zkoušce bude mimo měření spotřeby paliva $\mathrm{v}$ jednotkách $[\mathrm{kg} / \mathrm{h}]$ měřen i hmotnostní průtok vzduchu spotřebovávaný motorem, je možné produkci emisí vyjádřit nejenom v procentuálním podílu (vtaženém $\mathrm{k}$ celkovému objemu spalin), ale i v jednotkách [g/ $\mathrm{kWh}$, jak je uvedeno $\mathrm{v}$ grafu.

Na obr. 11 je pak uveden př́klad úplné charakteristiky spalovacího motoru osobního automobilu sestavené z vnější a několika částečných charakteristik (naměřených při nižší dávce paliva). Úplná (celková) charakteristika se uplatňuje při komplexním posuzování spalovacích motorů z hlediska výkonu, točivého momentu, spotřeby paliva, teplot, jednotlivých škodlivin ve výfukových plynech a př́ípadně dalších vedlejších veličin. Úplná charakteristika $\mathrm{v}$ jednom diagramu umožňuje zobrazit několik závislostí současně pomocí průsečíkových diagramů.

Dalším typem zkoušek, které jsou na válcové zkušebně prováděny, jsou zkoušky brzdového ústrojí. Na obr. 12 jsou vyneseny grafy brzdného zpomalení, rychlosti a brzdné dráhy v závislosti na čase. Výsledky jsou ze zkoušek brzd, které probíhaly dynamickou metodou při deaktivaci systému ABS. Brzdění probíhalo z rychlosti $80 \mathrm{~km} / \mathrm{h}$. Díky nezávislému válci zkušebny každého kola je hodnocení možné rovněž provést pro každé kolo ( $\mathrm{PP}$ - pravé přední, LP - levé přední, $\mathrm{PZ}$ - pravé zadní, $\mathrm{LZ}$ - levé zadní). $\mathrm{Z}$ tohoto důvodu lze mimo průběhu sledovaných parametrů hodnotit i jejich diference mezi jednotlivými koly.

Jak je z grafických závislostí patrné, tak hodnoty brzdného zpomalení, brzdné dráhy i času brzdění přesahují hodnoty dané příslušnou legislativou (EHK č. 13), které stanovují limity zmíněných parametrů pro osobní automobil. Je nutné, ale podotknout, že výsledky pocházejí ze zkoušek, při kterých byla síla na brzdový pedál omezena na $50 \mathrm{~N}$, tj. měření neprobíhalo s maximální brzdným účinkem kolových brzd.

Mimo tyto parametry je možné hodnotit i brzdnou sílu $F_{b}$ na obvodu kola, např. při monitorování funkce ABS se současným záznamem průběhu ovládací síly na brzdový pedál.

\section{ZÁVĚR}

Příspěvek měl za úkol popsat možnosti měření výstupních parametrů vozidla na válcové dynamometru. Zkoušky na válcových zkušebnách představují rychlou a velice přesnou alternativu $\mathrm{k}$ měření vozidel v reálním provozu, nebo k měření na motorových zkušebnách. Díky stálosti okolních a předem přesně definovaných podmínek měření je zajištěná opakovatelnost a vysoká statistická významnost naměřených hodnot. Právě tyto zmíněné přednosti měření na válcových zkušebnách předurčují tyto zkoušky pro využívání v oblasti soudního znalectví pro hodnocení stavu vozidel a jejich funkčních skupin. 


\section{PODĚKOVÁNÍ}

Tento prríspěvek byl vytvořen s podporou projektu ZETOR (EG15_019/0004799 - ZETOR TRACTORS a.s.) - Optimální agregace strojů s traktorem.

\section{LITERATURA}

[1] ŠTĚRBA, P., ČUPERA, J., POLCAR, A. Automobily Diagnostika motorových vozidel II. Avid, 2011, Brno, $181 \mathrm{~s}$. ISBN 978-80-87143-19-3.

[2] POLCAR, A. Analýza změn výstupních parametrů motorů při spalování paliva E85. Disertační práce, Mendelova univerzita v Brně, 2013, Brno.

[3] BAUER, F. a kol.: Traktory a jejich využití. 2. vyd., Profi Press, 2013, Praha, 224 s. ISBN 978-80-86726-52-6.
[4] MENDELOVA UNIVERZITA V BRNĚ, ÚSTAV TECHNIKY A AUTOMOBILOVÉ DOPRAVY: Vozidlová zkušebna pro osobní automobily. Databáze online [cit. 2018-12-27]. Dostupné na: http://web2.mendelu.cz/autozkusebna/docs/zkusebna.pdf

[5] VLK, F. Diagnostika motorových vozidel. Vlk, 2006, Brno, $442 \mathrm{~s}$. ISBN 80-239-7064-X.

[6] POLCAR, A., SEDLÁK, P., SKŘIVÁNEK, A. Assessment and Comparison of Accuracy of Data from CAN-Bus of Agricultural Tractors. In: Proceedings of the XLIV.International Scientific Conference of the Czech and Slovak Universitiy Departments and Institutions Dealing with the Research of Internal Combustion Engines KOKA 2013, Mendelova univerzita v Brně, 2013, Brno, 34-41 s. ISBN 978-80-7375-801-1.

[7] POLCAR, A., ČUPERA, J. Možnosti využití válcového dynamometru pro hodnocení stavu vozidel. In: Sborník př́spěvků konference Expert Forensic Science Brno 2019 - ExFoS 2019, 1. vyd., Vysoké učení technické v Brně, Ústav soudního inženýrství, 2019, Brno, 198-213 s. ISBN 978-80-214-5708-9.

\section{Správná citace:}

POLCAR, A., ČUPERA, J. Možnosti využití válcového dynamometru pro hodnocení stavu vozidel. Soudní inženýrství, 2019, 30(4), 3-11. DOI: http://dx.doi.org./10.13164/SI.2019.4.3. ISSN 1211-443X. 